\title{
Urban Sustainability Between Administrative Decision-Making and the Environment Source
}

\author{
Joan Ahmed ${ }^{1 *}$, Ahmed Saeed ${ }^{2}$ \\ ${ }^{1}$ Computer Engineering Department, Engineering College University of Mosul, Mosul 00964, Iraq \\ ${ }^{2}$ Construction and Projects Department, Headquarter, University of Anbar, Anbar 00964, Iraq
}

Corresponding Author Email: joan.akrawi@uomosul.edu.iq

https://doi.org/10.18280/ijsdp.150513

Received: 6 April 2020

Accepted: 10 June 2020

\section{Keywords:}

sustainability, environment, natural context, urban form, Administrative decision

\begin{abstract}
The study focused on reasons for creating, spreading and distributing pattern of land uses in "city of Khalidiya" in Anbar province in Iraq, especially expansion and slums areas. The research problem is concentrated in the spread of slums and their causes in two directions: first is an administrative decision and unbalanced planning in areas of expansion, while the second was the natural context in controlling the distribution of lands and crawling over agricultural areas without any planning of uses. The main objective of the research is to define the role of both natural context and administrative decisions in shaping the city of Khalidiya and to determine factors affecting lands, such as natural and human factors and spatial relationships, as well as collecting and clarifying information about lands, economic and social characteristics and services in the study area, as the statistical analysis was used to access to desired results. Model inputs were based on data sources, field surveys, and direct interviews with citizens and decision-makers in city council and urban planning directorate in the governorate. It was found that expansion of $\mathrm{Al}$ Khalidiya relies mainly on natural contexts with aim of filling housing deficit only, while all facilities and services were neglected as well as consumption of natural and human resources without thinking about sustainability. The city's layout reflects lack of any exploitation of agricultural areas, potential sites for tourism, renewable energy resources, and environmental and economic activities.
\end{abstract}

\section{INTRODUCTION}

The growth rates in most urban areas in Iraq is increasing. Rapid urbanization has led to an increased pace of residential and commercial development that replaces agriculture and another undeveloped surrounding land [1]. The rapid urbanization process, although has led to considerable development in the economy, industrialization and migration, has significantly increased land use. The problems of urban sprawl, loss of vegetation cover and the general decline in environmental quality can be attributed to an increase in population as the total land allocated to urbanization expands [2].

Land use and land cover are immensely important as they determine the nature and future performance of infrastructures [3]. Thus, urbanization has become synonymous with frequent changes in land use, which often negatively impacts on the environment. Moreover, poor and inefficient land management results in illogical urban development that antagonizes land suitability and expansion capacities, which leads to complex challenges faced by planners and policymakers. It may also lead to external factors as decisionmakers have often neglected to enable resources and absorptive capacity to develop major growth strategies for future [4]. Al-Khalidya is one of the Iraqi cities that have long suffered from the acquisition of small tracts of land that had structures arbitrarily built on them (irregularities). Hence, an imprint of randomness can be observed within or outside municipal boundaries. This randomness is due to competition for land, increasing population and immigrants without a concomitant increase in land area, and misuse of available land projected for specific purposes. Moreover, successive schemes have failed to draw up an effectual land development policy. The political factors that have rolled over the city in previous years have also influenced its planning process. Nonetheless, the municipality is now striving, in cooperation with the local council, to mitigate and reduce slums.

Given the proliferation of slums and endemic mismanagement of land use are rife, there is an urgent need to study patterns of land use, and then identify existing problems arising from improper planning and subsequent development of an optimum use strategy. The study of land uses and their sites on the master plan are valuable and beneficial to all aspects of development and achievement of desired and realistic objectives. Resolving this quagmire of land use constitutes an important and fundamental stage in development and planning of study area. Therefore, objectives of this study are to determine the role of both natural context and administrative decision in shaping the urban form of $\mathrm{Al}$ Khalidya City, and provide knowledge of factors influencing land uses, such as natural and human factors and spatial relationships, as well as compilation and clarification of information on land use, economic and social characteristics and services in the study area for decision-makers. Al Khalidya City was selected because of its important geographic location and expected future role as a vital hub and growth pool for agricultural, industrial and tourism activities, which has the greatest impact in enhancing its attraction of 


\section{URBAN FORM}

\subsection{The concept}

Cities are, in morphological terms, extremely complex objects. In other words, cities are objects composed of different objects or parts. It is possible to identify several relationships between these objects 'from part to whole' and to recognize a hierarchy in these relations (Figure 1). To deal with the complexity of cities, urban morphology uses this hierarchical view of the city, structured according to a set of fundamental physical elements [5].
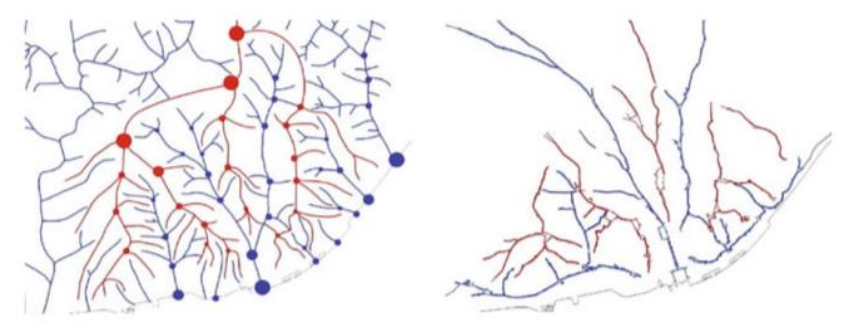

Figure 1. Physiography of physical support (ridges and thalwegs; distribution centres and encounter centres) and street system (ridge streets and thalweg streets) of Lisbon [6]

\subsection{The street system}

The streets system provides a way to systematically move around a given location and to gain knowledge about a city. Streets define different street blocks that constitute a city and differentiate what is public, and is thus accessible to all citizens, from what is private or semi-public. In general terms, streets are public and democratic spaces of the city, where everyone with their differences meets and socially interact [5].

\subsection{The plot system}

Plots system of a city is an important element of urban form that separates the public domain from the private domain. Nevertheless, the role of this fundamental system is often ignored by key agents and stakeholders in the process of city building, mainly due to apparent reduced urban visibility of plots.

\subsection{The building system}

The height of buildings is another important feature, particularly the relationship between the height of a building and width of the street they are located. Any variation in these two measures can initiate considerable changes in the urban landscape. If the height of a building is significantly less than street width, little sense can be made of the enclosure. On the other hand, if the height exceeds street width, sense of enclosure will increase [7].
Political factors: These factors play a major and influential role in shaping dimensions of realistic development. Given the circumstances of Iraq, people have been led to coexist with randomness and chaos of land use with disregard for law and controls initially in place [7]. Economic factors: These factors that affect the form of land use. The factors or conditions have led to the dominance of land issue in important and vibrant locations in the city. Thus, the land has become a trading commodity affecting the process of trade within the city (supply and demand) [8]. Social factors: These are outcomes of external and internal pressures that are related to human survival, and important to evaluating social-economic development and peoples' livelihood. They determine the extent to which a family and extended families can coexist in an independent dwelling unit. The factors include family structure, household life and social customs. These factors affect the design of the dwelling house, thereby controlling urban residential development plan [9]. General factors: These factors include conditions of the city and the nature of available services in it, and their importance compared to adjoining cities in terms of location, availability of jobs, road network, etc. These factors are important for Khalidya as it lies between two poles of attraction. Cultural factors: These play a significant role in the form of land use and distribution of activities, and actions of individuals in the city that reflect their inherited culture.

Administrative and planning factors: These are factors responsible or authorized to plan and manage the city, which is the municipality and Directorate of Physical Planning under the supervision and support of the local government. Given the inability and failure of local government to provide support for the municipality's decision, municipal officials are constantly confronted by violators in their attempts to remove irregularities [10].

\section{THE STUDY AREA}

The general characteristics of the study area are analyzed from two levels: regional and urban, because of their strong relations and interactions, particularly in suburbs. Al-Khalidya City in Anbar Governorate is located between two latitudes $33^{\circ} 22-33^{\circ} 26$ North and linear length of $43^{\circ} 48-43^{\circ} 49$ East, about $80 \mathrm{~km}$ away from Baghdad. Al-Khalidya City occupies $714 \mathrm{~km}^{2}$ (Figure 2). The surface of Khalidya area is generally flat and ranges from 35 to $103 \mathrm{~m}$ above sea level. The dominant features in the study area consist of four types, namely plateau, sedimentary plain, Euphrates River and Lake of Habbaniyah. The major natural resources in Khalidya area are Euphrates River and Habbaniyah lake in the south-east side, natural plants and mineral resources that include limestone (49\%), gypsum (24\%) and river sand (15\%). The disparity in numbers and proportions of the population is due to a natural increase in population (natality rate), improvement in the level of social services and amenities, and availability of employment which has encouraged stability. The average population density in the city is 53 persons per/ha. The number of inhabitants in 2018 is 58702 with 11309 households occupying 6367 housing units (Figure 3 and 4) and a family size rate of 5.9 (Table $1 \&$ Table 2 ). 


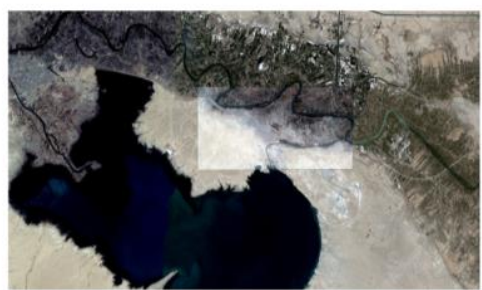

(a)

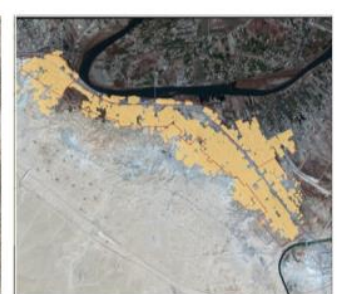

(b)
Figure 2. Khalidya: (a) regional, (b) land use/cover

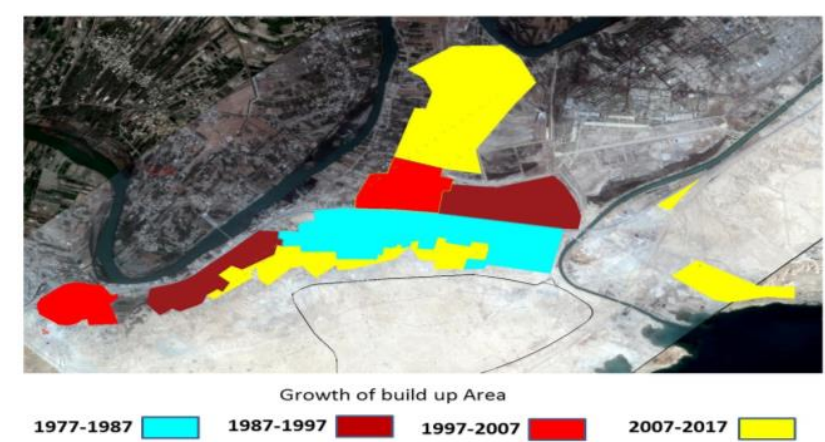

Figure 3. Map of the urban sprawl of Al-Khalidya city from 1977 to 2017

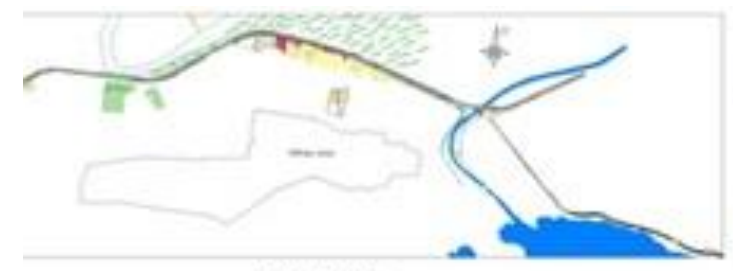

1977-1987

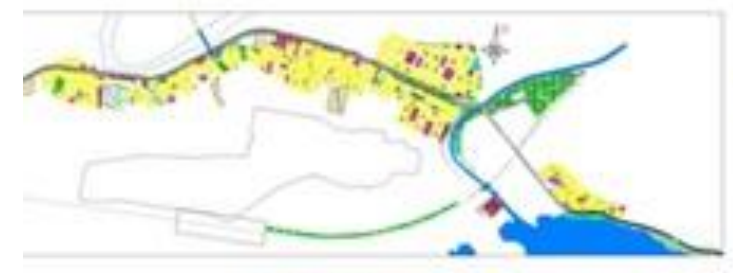

$1997-2007$
Table 1. Population growth distribution of Khalidya area starting from 1977

\begin{tabular}{cccccc}
\hline \multirow{2}{*}{ Year } & \multicolumn{5}{c}{ Population } \\
& Urban & $\%$ & Rural & $\%$ & Total \\
\hline 1977 & 20360 & 36 & 36129 & 64 & 56489 \\
1987 & 24148 & 39 & 37136 & 61 & 61284 \\
1997 & 29486 & 35 & 54754 & 65 & 84240 \\
2007 & 56051 & 61 & 35896 & 29 & 91947 \\
2018 & 58702 & 58 & 41752 & 42 & 100454 \\
\hline
\end{tabular}

Table 2. Urban sprawl and population growth in Al-Khalidya city starting from 1977 (Source: Figures 3\&5)

\begin{tabular}{|c|c|c|c|c|c|}
\hline \multirow{2}{*}{ Year } & \multicolumn{2}{|r|}{ Area } & \multicolumn{2}{|c|}{ Population } & \multirow{2}{*}{$\begin{array}{l}\text { Density } \\
\text { Per/ha }\end{array}$} \\
\hline & Ha. & $\%$ Growth/year & 1000 & $\%$ Growth/year & \\
\hline 1977 & 198 & - & 20360 & - & 103 \\
\hline 1987 & 245 & 2.13 & 24148 & 1.7 & 99 \\
\hline 1997 & 451 & 6.1 & 29486 & 2 & 65 \\
\hline 2007 & 602 & 2.8 & 46051 & 4.4 & 76 \\
\hline 2018 & 1124 & 6.24 & 58702 & 2.2 & 53 \\
\hline
\end{tabular}

Source: Researchers depend on central Statistical Organization/Anbar province

Figure 4. Evolution of the master plan of Al-Khalidya City over 40 years (4 stages). Source: Researchers
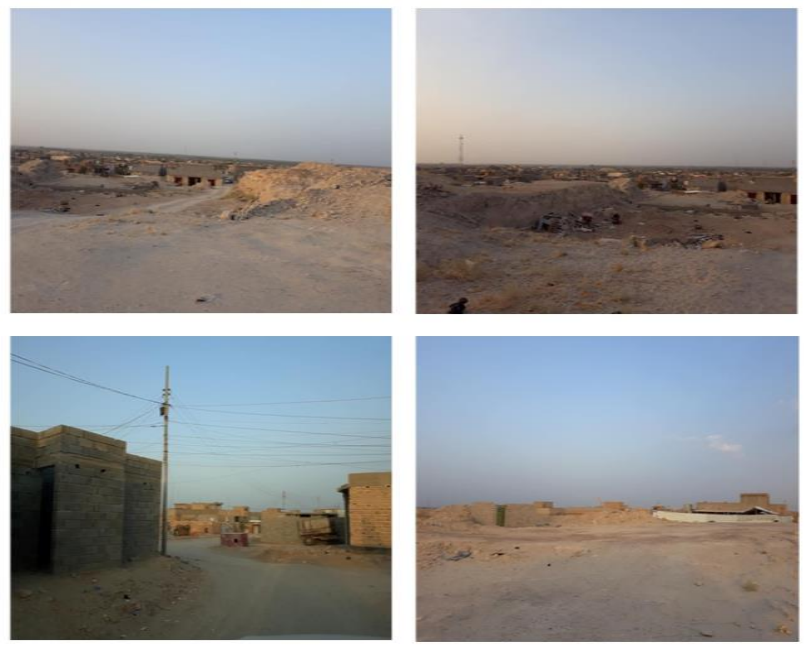

Figure 5. Khalidya, 2018: Illegal expansion indicating lack of planning or services. Source: Researchers

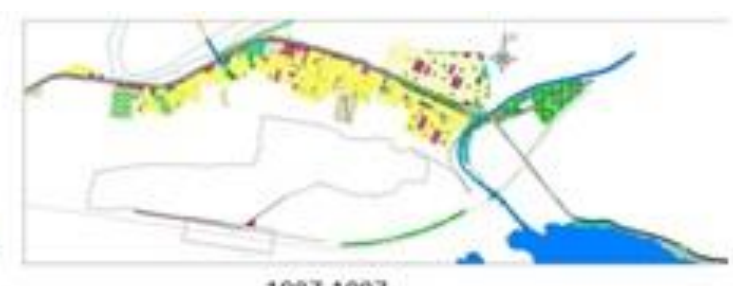

1987-1997

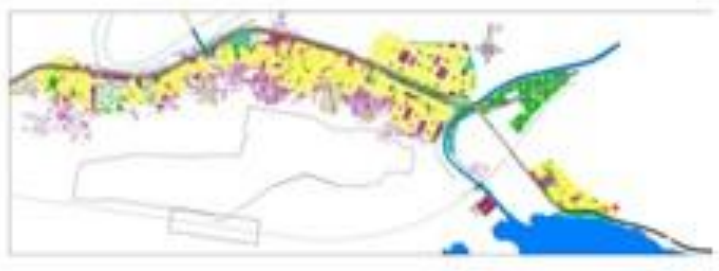

2007-2017
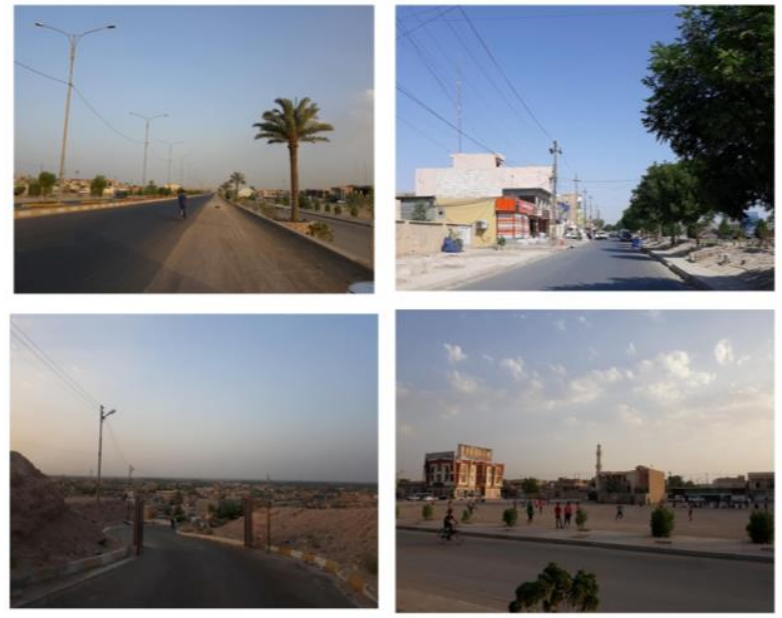

Figure 6. Khalidya, 2018: The existing urban shape with the dominance of linear distribution of land use and service. Source: Researchers 


\subsection{Patterns of urban form}

Linear distribution: Settlements according to this pattern shows a line along General road (Baghdad--Ramadi) and a railway (Baghdad-Syria). Clustered distribution: The settlement centres in this pattern of urban form comprise regular and irregular gatherings that are characterized by small size area and large population growth. Scatter distribution: Here, centres of settlements are distributed indiscriminately over a wide area of land (Figure 5 and Figure 6). The prevalence of this pattern of settlement is widely observed. The appearance of this pattern is due to several causes that include scarcity of water resources and high incidence of individual ownership [2].

\subsection{Economic activities}

Agriculture: Total area occupied by rural expanses is 14895 ha, but suitable agriculture area is only 5059 ha (34\%). The area under cultivation did not exceed $68.7 \%$ of the total arable land in the area. Crops in the area include seeds, vegetables, tuber crops, fodder crops and palm groves. Animal production is carried out in 4.8 ha of the area under exploitation with 57 poultry fields covering an area of 10.25 ha. Industry and Tourism: The city's administration does not currently have a practical plan for exploiting natural resources to revive its industrial potential. Moreover, there is no appropriate design plan for the development of the city and its territory. Tourism depends only on natural elements and is not related to human aspects of archaeological and historical sites [11].

Table 3. Land use and coverage rates in Khalidiya by urban planning directorate

\begin{tabular}{ccc}
\hline Land use & Area /ha & \% \\
\hline Residential & 199.36 & 33.66 \\
Educational & 7.42 & 1.25 \\
Health & 1.19 & 0.20 \\
Commercial & 2.73 & 0.46 \\
Government offices & 3.35 & 0.57 \\
Public Services & 2.4 & 0.40 \\
Religious & 2.81 & 0.47 \\
Industrial & 0.63 & 0.11 \\
Warehouses & 0.56 & 0.09 \\
Green area & 7.19 & 1.22 \\
Sport & 1.48 & 0.25 \\
Cemeteries & 7.55 & 1.28 \\
Irregularities (slums) & 236.67 & 39.96 \\
Vacancy & 153.66 & 25.97 \\
Roads and squares & 201.64 & 34.07 \\
Total area / ha & 591.97 & 100 \\
Source: researchers depend on Khlidiya municipal \\
\hline
\end{tabular}

\subsection{Urban land use}

The area of Khalidya city is 235.5 ha. There are no archaeological or cultural monuments in the city, as it is a modern city. It is also devoid of civilizational monuments being a small city. It should be noted that there are disparities in the levels of construction, as there are many luxury mansions and large villas, as well as simple old-style houses. Two major trends in land use/coverage can be identified between 1997 and 2017: intensification of urbanization in central areas where a few open areas and hills have been occupied to accommodate residential use, and urbanization in semi-urban/suburban areas, where urbanization is increasingly being expanded at expense of permanent crops and palm groves. However, the distribution of services did not consider the needs of residents and is not based on a specific criterion. Due to uncontrolled growth, land on which the services were constructed only spaces within crowded fabric [12], Table 3 shows rates of land use.

\section{METHODOLOGY}

The methodology used in research aims to evaluate the effect of variables of an administrative decision on the current urban form on one hand, and another hand effect of variables related to the natural context on urban form. Knowing these effects makes them an indication for setting future solutions for the city of Khalidiya, especially the distribution of land uses and services and access to a typical urban form that planners and decision-makers in city aspire to in support of the final design of the city, which provides a good ground for investment, especially tourism and education because of the presence of great developmental and city potential.

\subsection{Data sources}

The data analyzed was obtained from central departments and institutions in Baghdad and Anbar province. Regional field reconnaissance of city and its suburban was also embarked on with accompanying recording of phenomena and observations. This study also relied on direct meetings with community personalities responsible for technically managing city and personalities that have archived knowledge of the city. Other sources of data include topographic maps issued by General Surveying Institute, spot satellite images (2008, R.14m) and Quik Bird satellite images (2008, R.0.6m). Large and medium-sized enterprises, as well as industrial and commercial activities, were also surveyed for data on economic activities and employment.

\subsection{Statistical analysis}

The SPSS program was used to calculate the effect of indicators on the context of natural expansion and planning decision making. The inputs of the model were based on data sources, field surveys and direct interviews with citizens and decision-makers in city council and directorate of urban planning in the governorate. Table 4 shows the concept of indicators and their expected impacts by program output.

Thus, the formula of the model is as follows:

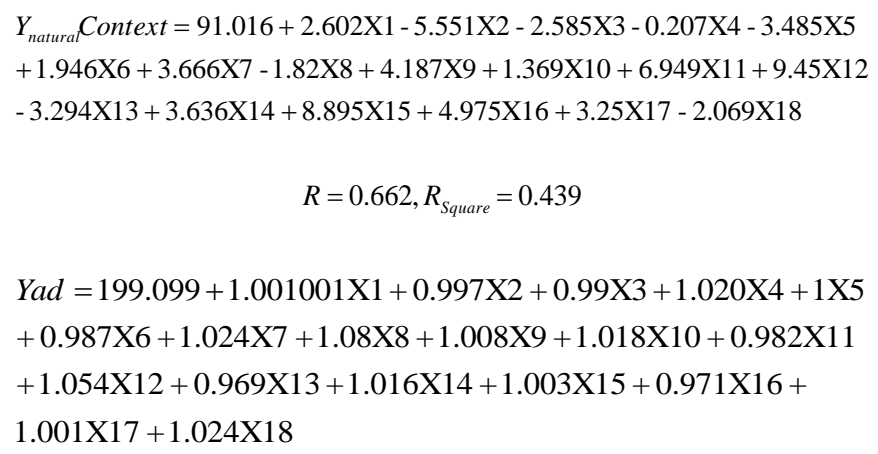

$$
R=0.811, R_{\text {Square }}=0.657
$$


Table 4. Increasing and decreasing effects (respectively) of indicators on natural context and administrative decision

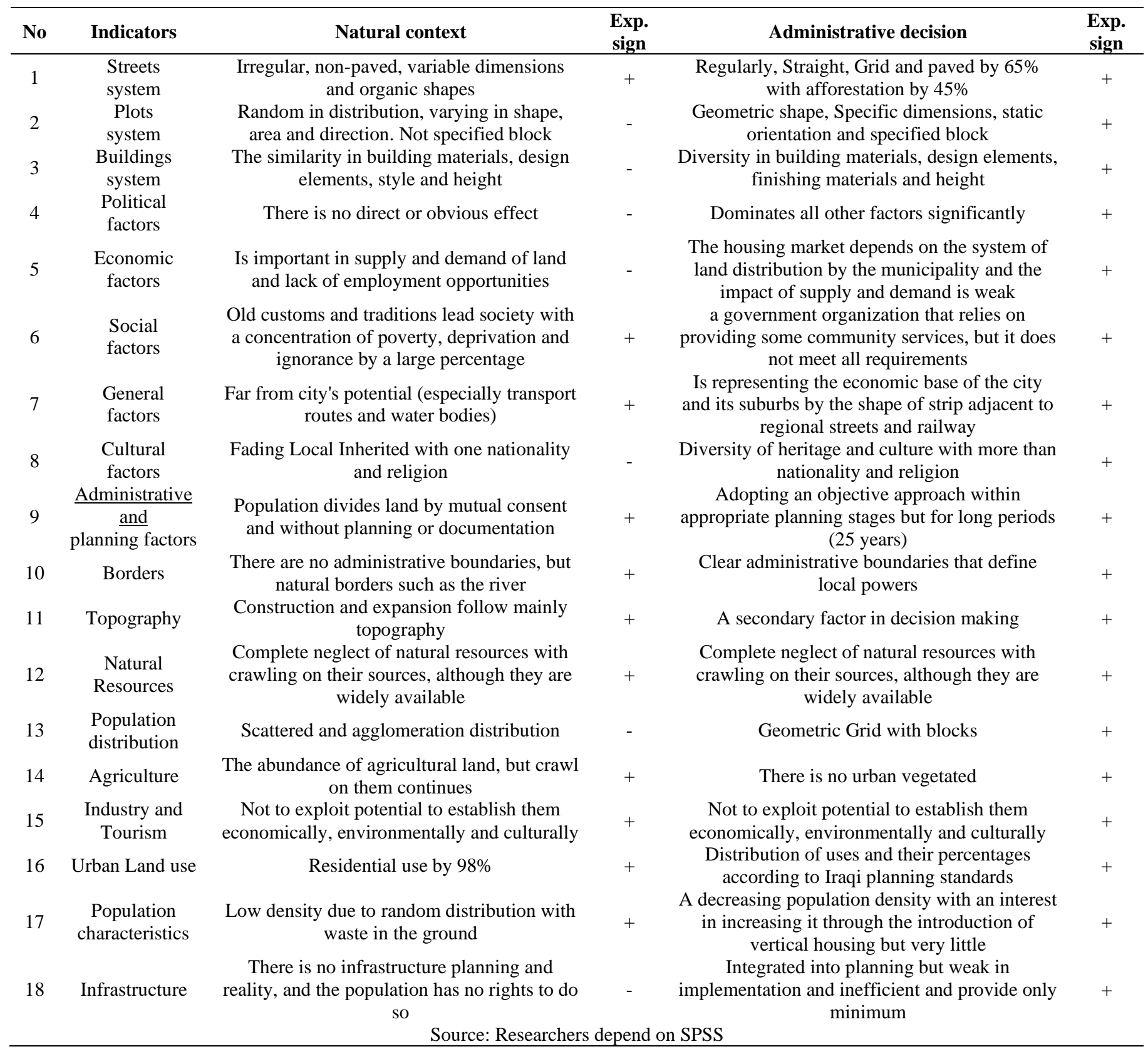

\section{RESULTS AND DISCUSSION}

From Tables $5 \& 6$ representing the output of SPSS program, the following points were deduced:

- Expansion of Khalidiyah was mainly based on natural contexts (social and economic) with the intent of only filling housing deficit, while all utilities and services, as well as consumption of natural and human resources, were neglected with no thought given to sustainability.

- Planning of the city reflects lack of any exploitation of agricultural areas, potential sites of tourism and renewable energy resources, specifically solar and wind. Possible areas of expansion were not identified. Moreover, planning lacks environmental and economic acuities.

- Planning and design decisions were based on traditional standards that are inconsistent with ICT or Eco-cities, although there are possibilities for their application. This is evident from an imbalance in land use and distribution ratios in the master plan prepared by decision-makers (Figure 7).

- There is a large gap between the city's stakeholders, which has led to conflicts in design decisions, thus urban form and all stakeholders involved have completely moved away from elements of sustainability in their entirety.

- A level of planning criteria should be developed in replanning of the city, starting from regional level and its natural and human potentials and it can positively impact on a local level. At the local level, city of Khalidya needs to plan, redevelop and activate the role of urban design in identifying elements of sustainable urban form, especially conservation of natural resources. Principles of green architecture need to be introduced to increase the percentage of green areas and open spaces. 
Table 5. SPSS program outputs about natural context

\begin{tabular}{|c|c|c|c|c|c|c|}
\hline \multirow{3}{*}{ Model } & \multicolumn{6}{|c|}{ Coefficients $^{\text {(a) }}$} \\
\hline & \multirow{2}{*}{$\begin{array}{c}\text { Unstandardized } \\
\text { Coefficients } \\
\text { B }\end{array}$} & \multirow{2}{*}{$\begin{array}{c}\text { Standardized } \\
\text { Coefficients } \\
\text { Std. Error }\end{array}$} & \multirow[b]{2}{*}{ Beta } & \multirow[b]{2}{*}{$\mathrm{t}$} & \multicolumn{2}{|c|}{$\begin{array}{l}95.0 \% \text { Confidence Interval for } \\
\text { B }\end{array}$} \\
\hline & & & & & Lower Bound & Upper Bound \\
\hline (Constant) & 91.016 & 21.045 & & 4.325 & 48.094 & 133.937 \\
\hline Streets system & 2.602 & 2.350 & .184 & 1.107 & $-2.192-$ & 7.396 \\
\hline Plots system & $-5.551-$ & 2.475 & $-.372-$ & $-2.243-$ & -10.598 & $-.504-$ \\
\hline Buildings system & $-2.585-$ & 2.164 & $-.212-$ & $-1.195-$ & $-6.998-$ & 1.828 \\
\hline Political factors & $-.207-$ & 3.118 & $-.012-$ & $-.066-$ & $-6.566-$ & 6.152 \\
\hline Economic factors & $-3.485-$ & 4.012 & $-.151-$ & $-.869-$ & $-11.668-$ & 4.698 \\
\hline Social factors & 1.946 & 3.055 & .099 & .637 & $-4.284-$ & 8.177 \\
\hline General factors & 3.666 & 4.731 & .159 & .775 & $-5.983-$ & 13.315 \\
\hline Cultural factors & $-1.820-$ & 3.324 & $-.117-$ & $-.548-$ & $-8.599-$ & 4.959 \\
\hline Administrative and planning factors & 4.187 & 2.974 & .241 & 1.408 & $-1.879-$ & 10.254 \\
\hline Borders & 1.396 & 3.105 & .096 & .450 & $-4.937-$ & 7.728 \\
\hline Topography & 6.949 & 2.503 & .552 & 2.776 & 1.844 & 12.054 \\
\hline Natural Resources & 9.450 & 4.686 & .403 & 2.017 & $-.107-$ & 19.008 \\
\hline population distribution & $-3.294-$ & 3.175 & $-.215-$ & $-1.038-$ & $-9.770-$ & 3.182 \\
\hline Agriculture & 3.636 & 2.613 & .265 & 1.392 & $-1.693-$ & 8.964 \\
\hline Industry and Tourism & 8.895 & 5.944 & .274 & 1.496 & $-3.229-$ & 21.018 \\
\hline & 4.975 & 6.117 & .148 & .813 & $-7.500-$ & 17.451 \\
\hline & 3.250 & 2.435 & .220 & 1.335 & $-1.716-$ & 8.217 \\
\hline & $-2.069-$ & 4.001 & $-.092-$ & $-.517-$ & $-10.230-$ & 6.091 \\
\hline
\end{tabular}

Table 6. SPSS program outputs about administrative decision

\begin{tabular}{|c|c|c|c|c|c|c|}
\hline \multirow{3}{*}{ Model } & \multirow{3}{*}{$\begin{array}{c}\text { Unstandardized } \\
\text { Coefficients } \\
\text { B }\end{array}$} & \multicolumn{3}{|c|}{ Coefficients ${ }^{\text {(a) }}$} & \multirow{2}{*}{\multicolumn{2}{|c|}{$\begin{array}{l}\text { 95.0\% Confidence Interval for } \\
\text { B }\end{array}$}} \\
\hline & & $\begin{array}{l}\text { Standardized } \\
\text { Coefficients }\end{array}$ & & & & \\
\hline & & Std. Error & Beta & $\mathrm{t}$ & Lower Bound & Upper Bound \\
\hline (Constant) & 199.593 & .287 & & & 199.009 & 200.178 \\
\hline Streets system & 1.001 & .024 & .211 & 42.030 & .952 & 1.049 \\
\hline Plots system & .997 & .019 & .264 & 51.260 & .957 & 1.036 \\
\hline Buildings system & .990 & .016 & .293 & 63.175 & .958 & 1.022 \\
\hline Political factors & 1.020 & .023 & .216 & 44.431 & .973 & 1.067 \\
\hline Economic factors & 1.000 & .021 & .262 & 48.541 & .958 & 1.042 \\
\hline Social factors & .987 & .029 & .186 & 34.609 & .928 & 1.045 \\
\hline General factors & 1.024 & .018 & .285 & 56.136 & .987 & 1.061 \\
\hline Cultural factors & 1.080 & .034 & .172 & 31.581 & 1.010 & 1.149 \\
\hline Administrative and planning factors & 1.008 & .027 & .208 & 37.959 & .954 & 1.062 \\
\hline Borders & 1.018 & .032 & .173 & 31.722 & .952 & 1.083 \\
\hline Topography & .982 & .045 & .123 & 21.694 & .890 & 1.075 \\
\hline Natural Resources & 1.054 & .043 & .137 & 24.247 & .966 & 1.143 \\
\hline population distribution & .969 & .039 & .138 & 24.617 & .889 & 1.049 \\
\hline Agriculture & 1.016 & .020 & .261 & 51.460 & .976 & 1.056 \\
\hline Industry and Tourism & 1.003 & .019 & .282 & 52.634 & .964 & 1.042 \\
\hline
\end{tabular}

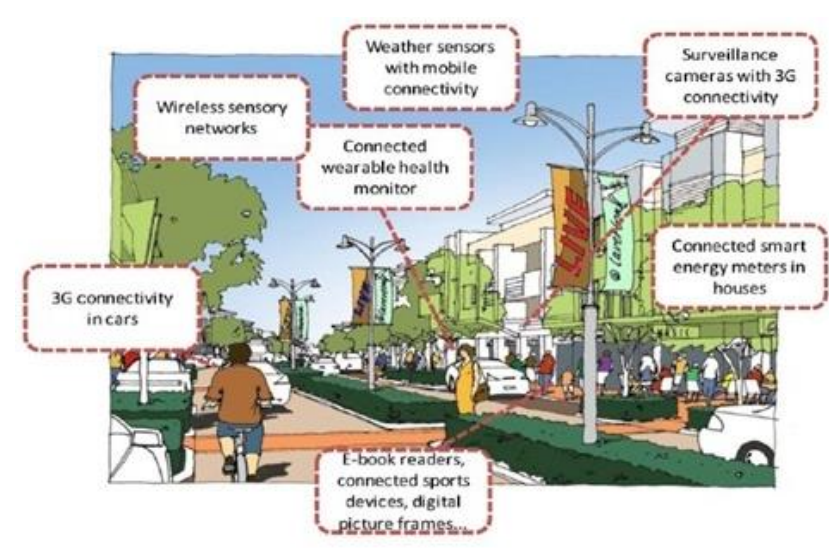

(a)

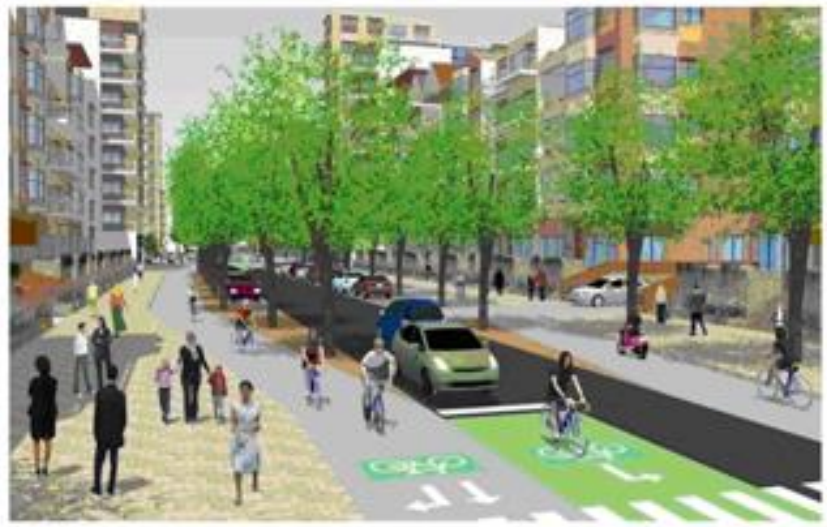

(b) 


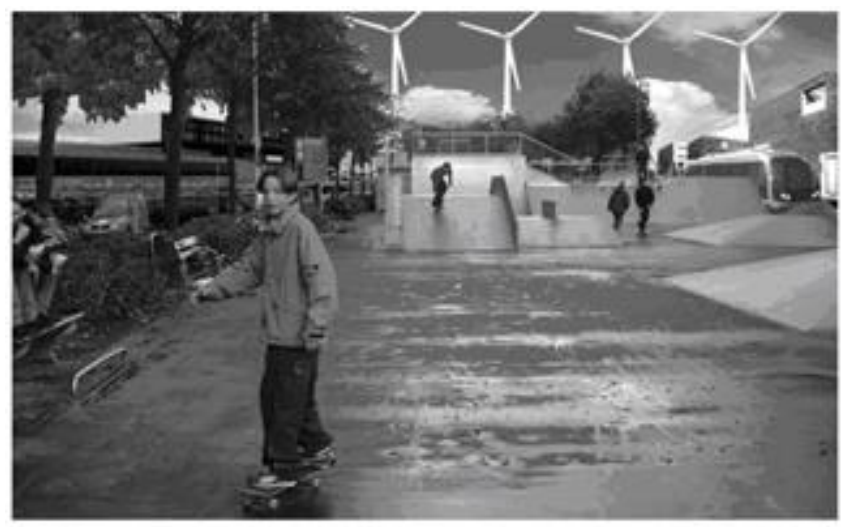

(c)

Figure 7. Concepts of (a) ICT city, (b) Green street, and (c) Eco-cities [13]

\section{CONCLUSIONS}

1) Organic (experimental) form dominates urban expansion according to natural context, with a multiplicity of areas and forms of land, street systems, lack of progression and different forms of land.

2) Lack of a clear contract or arenas that perform social, cultural and entertainment functions. As for edges, they are not specified. Even if these edges are found, some of them are removed or overlooked, such as in cutting hills or prohibitions of transmission lines.

3) Clarity of the geometric (rational) geometry and the distribution of elements of urban form in planned neighbourhoods within the master plan, especially grid and striped shape with the unity of street shapes and their scale, and the dimensions of the plots and their shapes within sectors (engineering blocks).

4) Land uses within the natural context are dominated by residential use by up to $70 \%$, with a small percentage of religious use (mosques and cemeteries), retail stores, and the lack of other uses.

5) Land use is distributed within administrative decision according to Iraqi planning standards, but they are not parallel with urban and population growth or technical development.

6) Clear waste of natural resources and capabilities within administrative boundaries of the city of Khalidiya and change natural shape, especially cutting distinctive hills of the plateau and crawling on natural plant and water bodies as well as converting them to places for waste collection and sanitation.

7) Population and housing density in urban sprawl areas decreased significantly, which means waste inland areas, as most of the housing units have one ground floor with the deteriorating level of design and building materials. 8) A clear variation in land prices between natural crawling areas and lands within boundaries of the master plan, as price per square meter in planned areas, reaches more than ten times its price in areas of expansion (overtaking), while confirming that owners do not obtain a title to land that guarantees rights in future.

9) Weakness in implementing the administrative decision, especially in accounting for abuses in general and on agricultural lands and natural resources, and we rarely find a measure that prevents or limits continuity of abuses, which encouraged their continuation to date.
10) Results of field study showed that rate of urban sprawl varied during four decades in terms of area growth rate and ranged between $2.23 \%$ in 1987 to $6.24 \%$ in 2018 , and reason for this is due to the weak role of law in the last decade and its lack of influence in the application Administrative decision.

11) The low population density in the center of the Khalidiya district in urban expansion area outside the master plan and ranged between 103 people/hectares in 1977 to 53 people/hectares in 2018 due to large area and lack of planning in the expansion areas, and failure to follow the planning standard in expansion areas Uncontrolled.

12) Lack of community services (educational, health and cultural) and infrastructure services in urban expansion areas. Which puts pressure on main services in the city.

13) Service access distance is greater than the standard of (500) $\mathrm{m}$ as a maximum, according to planning standards.

\section{ACKNOWLEDGEMENTS}

The research team would like to thank the University of Mosul and the Office of ESSAT for its contribution in providing us with data and maps, and Consultant Eng. Inam Ghazi Ali for facilitating the task of interviews and photography, and Dr Ziad Al Sarraf for programming and facilitating the packages.

\section{REFERENCES}

[1] Cerreta, M., De Toro, P. (2012). Urbanization suitability maps: A dynamic spatial decision support system for sustainable land use. Earth System Dynamics, 3(2): 157171. https://doi.org/10.5194/esd-3-157-2012

[2] Černe, A. (2004). Dispersed and decentralised settlement system. Dela, 21: 83-95. https://doi.org/10.4312/dela.21.6.83-95

[3] Williams, K. (2014). Urban form and infrastructure: a morphological review. Future of Cities, University of the West of England, Bristol.

[4] Frenkel, A., Ashkenazi, M. (2008). Measuring urban sprawl: How can we deal with it? Environment and Planning B: Planning and Design, 35(1): 56-79. https://doi.org/10.1068/b32155

[5] Caliskan, O., Marshall, S. (2018). Urban morphology and design: Introduction. Built Environment, 37(4): 381392. https://doi.org/10.2148/benv.37.4.381

[6] Kropf, K. (2018). The elements of urban form. In V. Oliveira. Urban Morphology: An Introduction to the Study of the Physical Form of Cities. AG, Switzerland: Springer Nature, 7-30.

[7] Herold, M., Liu, X., Clarke, K.C. (2003). Spatial metrics and image texture for mapping urban land use. Photogrammetric Engineering \& Remote Sensing, 68(9): 991-1001. https://doi.org/10.14358/PERS.69.9.991

[8] Cullen, G. (2012). Concise Townscape ( $1^{\text {st }}$ ed.). London: Routledge.

[9] Mossay, P., Picad, P. (2019). Spatial segregation and urban structure. Journal of Regional Science, 59(3): 480507. https://doi.org/10.1111/jors. 12442

[10] Bramley, G., Kirk, K. (2005). Does planning make a difference to urban form? Recent evidence from Central Scotland. Environment and Planning A, 37(2): 355-378. https://doi.org/10.1068/a3619 
[11] van Raan, A.F., Der Meulen, G., Goedhart, W. (2016). Urban scaling of cities in the Netherlands. PloS One, 11(1): https://doi.org/10.1371/journal.pone.0146775

[12] Litman, T. (2016). Determining optimal urban expansion, population and vehicle density, and housing types for rapidly growing cities. The World Conference on
Transport Research, Shanghai, China.

[13] Mike, J., Nicola, D. (2005). Future Forms and Design for Sustainable Cities. Elsevier, pp: 270. https://www.routledge.com / Future-Forms-and-DesignFor-Sustainable-Cities/Jenks-

Dempsey/p/book/9780750663090. 